\title{
Rorscharchista until the Last Breath of Life
}

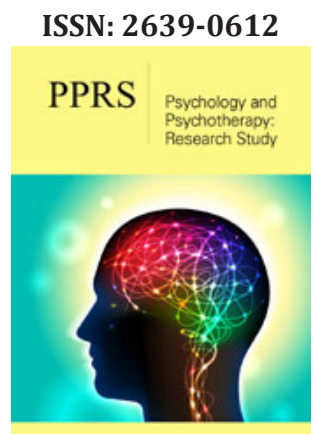

*Corresponding author: Jesus Dueñas Becerra, Departemnt of Pyscology, Cuba

Submission: 眥 February 11, 2020

Published: 監February 14, 2020

Volume 3 - Issue 3

How to cite this article: Jesus Dueñas Becerra. Rorscharchista until the Last Breath of Life. Psychol Psychother Res Stud. 3(3).PPRS.000564.2020.

DOI: 10.31031/PPRS.2020.03.000564

Copyright@ Jesus Dueñas Becerra, This article is distributed under the terms of the Creative Commons Attribution 4.0 International License, which permits unrestricted use and redistribution provided that the original author and source are credited.

\section{Jesus Dueñas Becerra*}

Departement of Pyscology, Cuba

\section{Opinion}

Dr. Elsa Pradere Campos (1928-1996), was not only a relevant personality of Cuban psychology, but also a passionate lover of the use of Rorschach Psychodiagnostic, a personality research method, scientifically and artistically designed by the brilliant Swiss psychiatrist Hermann Rorschach (1884-1922); work tool used by her in the clinical area and in cultural research. Pradere Campos was a doctor in pedagogy from the University of Havana and studied academics, which began at the School of Psychology at the José Martí Masonic University, and culminated in the School of psychology at the Martha Abreu de Las Villas Central University, founded in 1961, and where we met when the author of this literary evocation was studying at the Alma Mater villa from that moment on, between Elsa and I a professional relationship was established first, and then emotional-spiritual, which remained untouched until he left to meet the Universal Spirit in that magical world full of music, poetry, light and color, where the souls of good people like her go, who, when saying Martian, "love and believe."

Dr. Pradere Campos was a full professor of medical psychology at the university of medical sciences of Havana. Despite the teaching-educational functions that he played in that prestigious center of higher medical education, he never abandoned the care work, which he practiced at the adolescent clinic, where he had a weekly consultation in which he applied the rorschach psychodiagnostic to children and adolescents whom I attended in that institution of child and adolescent mental health, as I did with the students of the subject medical psychology at the institute of basic and pre-clinical sciences Victoria de Girón. The results of these Rorscharchian researches-carried out in the clinical, academic and cultural areas, fundamentally-were published in the printed version of the journal of the psychiatric hospital of Havana (1959-2000) and of the psychology bulletin (1978-1998), as well as in other specialized media of the flat island press.

The illustrious psychologist and university professor was the first Cuban rorscharchista to enter the field of culture, and in addition, she held the presidency of the Cuban society of psychology, founded in 1955 by Dr. Alfonso Bernal del Riesgo (1902-1975) until 1960 in which it was dissolved and absorbed by the then Cuban society of psychiatry and neurology. I could not finish without first referring to an anecdote that was recorded forever in my poetic memory. The same year that Dr. Elsa Pradere Campos died, as a result of a malignant condition, I decided to present a paper about the teaching of medical psychology, a subject she taught during most of her professional life, and I dedicated it to her. The original, typed, was sent to the teaching clinical-surgical hospital Hnos. Ameijeiras, where I had been held for some time. As she was in very bad health, she could not read the paper, and asked one of the children to do so. While her offspring read the content of the article, which synthesized the sui generis pedagogical methods used by her to teach Medical Psychology, the impact it caused was of such emotional-emotional magnitude that she and everyone around her bed, burst into tears That anecdote told me-with tears in her eyes-her daughter, Dr. Elsa Araújo Pradere, a psychiatrist at the clinical-surgical hospital Dr. Joaquín Albarrán, where Dr. Pradere Campos also practiced clinical psychology and applied the rorschach psychodiagnostic. Eternal glory to the memory of Elsa Pradere Campos, since he fulfilled-by far-the work of life, and therefore, can show it to heaven, with legitimate pride. 